\title{
Identification of Cu's high settling region in Jiaozhou Bay
}

\author{
Dongfang Yang, 2, 3, a , Weimin Ma ${ }^{4}$, Zhikang Wang ${ }^{1,2}$, Xiuzhen Tao ${ }^{1,2}$, Sixi Zhu ${ }^{1,2}$ \\ ${ }^{1}$ Research Center for Karst Wetland Ecology, Guizhou Minzu University, Guiyang 550025, China; \\ ${ }^{2}$ College of Chemistry and Environmental Science, Guizhou Minzu University, Guiyang 550025, China; \\ ${ }^{3}$ North China Sea Environmental Monitoring Center, SOA, Qingdao 266033, China; \\ ${ }^{4}$ China Satellite maritime tracking and control department, Jiangyin 214431, China. \\ adfyang_dfyang@126.com
}

Keywords: Cu; Settling; Horizontal distribution; Accumulation; Jiaozhou Bay.

\begin{abstract}
Cu}$ pollution in marine bay has been one of the environmental issues in the world, and understanding the transporting process of $\mathrm{Cu}$ is essential to environmental protection. This paper analyzed the horizontal distributions of $\mathrm{Cu}$ in bottom waters in Jiaozhou Bay, and identified the high settling regions based on investigation data on Cu during 1982-1985. Results showed that there were rapid settling processes in the bay, and a big part of $\mathrm{Cu}$ was transported to bottom waters. Furthermore, there were accumulation processes in these high settling regions. These findings were helpful information in decision-making of pollution control and environmental remediation practice.
\end{abstract}

\section{Introduction}

$\mathrm{Cu}$ has been widely used in everyday life for thousands of years. After the industrial revolution, both economy and population size were increasing rapidly, and a large amount of pollutants were generating and discharging to the environment. Nowadays, many marine bays have been polluted by $\mathrm{Cu}$ since ocean is the sink of pollutant [1-6]. Hence, understanding the transporting process of $\mathrm{Cu}$ in marine bay is essential to marine environment protection and the maintaining of ecological sustainable development.

Jiaozhou Bay is a semi-closed marine bay in Shandong Province China. This bay has been polluted by various pollutants including $\mathrm{Cu}$ after the reform and opening-up [7-16]. Based on investigation data on $\mathrm{Cu}$ during 1982-1985, this paper analyzed the horizontal distributions of $\mathrm{Cu}$ in bottom waters in Jiaozhou Bay, and identified the high settling regions. The aim of this paper was to provide information for scientific research and pollution control and environmental remediation.

\section{Study area and data collection}

Jiaozhou Bay is located in the south of Shandong Province, eastern China $\left(35^{\circ} 55^{\prime}-36^{\circ} 18^{\prime} \mathrm{N}\right.$, $\left.120^{\circ} 04^{\prime}-120^{\circ} 23^{\prime} \mathrm{E}\right)$. The total area, average water depth and bay mouth width are $446 \mathrm{~km}^{2}, 7 \mathrm{~m}$ and $3 \mathrm{~km}$, respectively. This bay is a typical of semi-closed bay which is connected to the Yellow Sea in the south. There are a dozen of rivers, and the majors are Dagu River, Haibo Rriver, Licun Rriver, and Loushan Rriver etc., all of which are seasonal rivers [17-18]. The investigation on Cd in surface waters in Jiaozhou Bay was carried on in July 1982, September 1983, July 1984 and October 1985, respectively [13-16] (Fig. 1). Cu in waters was sampled and monitored follow by National Specification for Marine Monitoring [19]. 


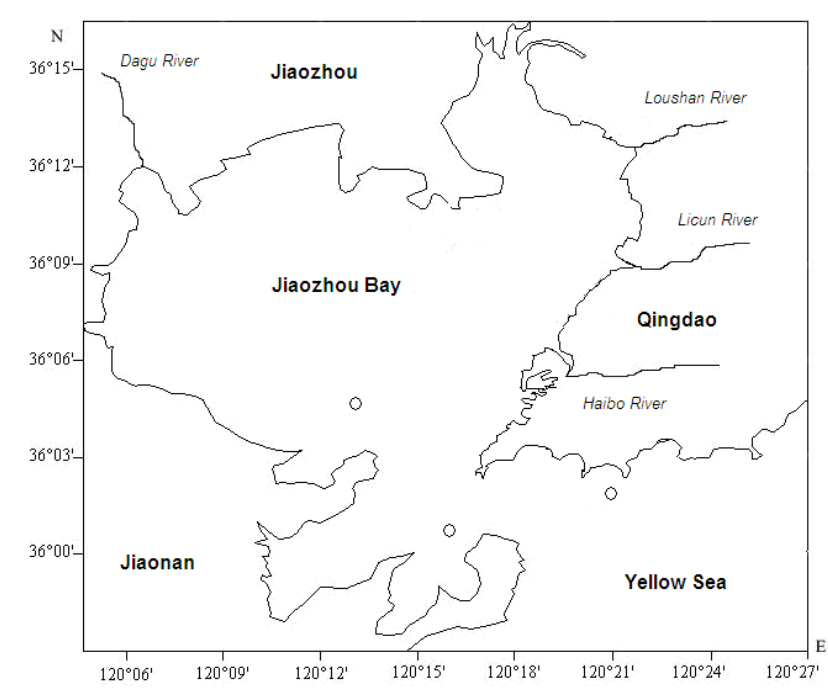

Fig. 1 Geographic location and sampling sites in Jiaozhou Bay

\section{Results and discussion}

$\mathrm{Cu}$ contents in bottom waters in Jiaozhou Bay in July 1982, September 1983, July 1984 and October 1985, were 0.23-1.46 $\mu \mathrm{g} \mathrm{L} \mathrm{L}^{-1}, 1.31-1.90 \mu \mathrm{g} \mathrm{L}^{-1}, 0.13-2.97 \mu \mathrm{g} \mathrm{L}^{-1}$, and 0.19-0.30 $\mu \mathrm{g} \mathrm{L}^{-1}$, respectively. In according to the guide line of $\mathrm{Cu}$ in National Sea Water Quality Standard (GB 3097-1997), all of the contents of Cu were lower than the guide line of Class I $\left(<5.00 \mu \mathrm{g} \mathrm{L}^{-1}\right)$. It could be concluded that $\mathrm{Cu}$ contents in bottom waters in Jiaozhou Bay in study years were still very low, and the pollution level was still slight.

The horizontal distributions of $\mathrm{Cu}$ contents in bottom waters were important evidences for identifying the settling process of $\mathrm{Cu}$. In July 1982, there was a high value center in coastal waters in the southwest of the bay $\left(1.46 \mu \mathrm{g} \mathrm{L}^{-1}\right)$, and the contour lines of $\mathrm{Cu}$ contents were forming a series of parallel lines that decreasing from the southwest of the bay to the center of the bay $\left(0.29 \mu \mathrm{g} \mathrm{L}^{-1}\right)$ (Fig. 2). It could be defined that there was a high settling region in the coastal waters in the southwest of the bay in July 1982. In September 1983, there was a high value center in coastal waters in the east of the bay $\left(1.90 \mu \mathrm{g} \mathrm{L}^{-1}\right)$, and the contour lines of $\mathrm{Cu}$ contents were forming a series of parallel lines that decreasing from the east of the bay to the o[en waters $\left(1.31 \mu \mathrm{g} \mathrm{L}^{-1}\right.$ ) (Fig. 3 ). It could be defined that there was a high settling region in coastal waters in the east of the bay in September 1983. In July 1984, there was a high value center in the bay mouth $\left(2.97 \mu \mathrm{g} \mathrm{L}^{-1}\right)$, and the contour lines of $\mathrm{Cu}$ contents were forming a series of parallel lines that decreasing from the east of the bay to the open waters $\left(0.13 \mu \mathrm{g} \mathrm{L}^{-1}\right)$ (Fig. 4). It could be defined that there was a high settling region in the bay mouth in July 1984. In October 1985, there was a high value center in coastal waters in the east of the bay $\left(0.30 \mu \mathrm{g} \mathrm{L}^{-1}\right)$, and the contour lines of $\mathrm{Cu}$ contents were forming a series of parallel lines that decreasing from the east of the bay to the bay mouth $\left(0.19 \mu \mathrm{g} \mathrm{L}^{-1}\right)$ (Fig. 5). It could be defined that there was a high settling region in coastal waters in the east of the bay in October1985.

In general, there was different high settling region of $\mathrm{Cu}$ in different months, the reason was that the source input of $\mathrm{Cu}$ was different in different season, and the sedimentation of $\mathrm{Cu}$ was also different in different season. A large amount of anthropogenic $\mathrm{Cu}$-containing waste was generated and discharged to the environment, and was transported to marine bays by means of terrestrial process and oceanic process. A big part of $\mathrm{Cu}$ was settling to the bottom waters and then was fixed to the sediment by gravity settling, bio-deposition and chemical action. The growth and reproduction of marine organism were increasing in spring, reaching the climax in summer, and then decreasing from autumn. The growth and reproduction of plankton were generating a lot of colloids in surfaces of the suspended particulate matters, and were enhancing the absorption ability of $\mathrm{Cu}$ the suspended particulate matters, resulting in the rapid settling of $\mathrm{Cu}$ to bottom waters. 
Hence, the settling of $\mathrm{Cu}$ to bottom waters was varying among seasons. By means of horizontal water's effect, vertical water's effect, resulting the high value regions of $\mathrm{Cu}$ in bottom waters in Jiaozhou Bay [20-22].

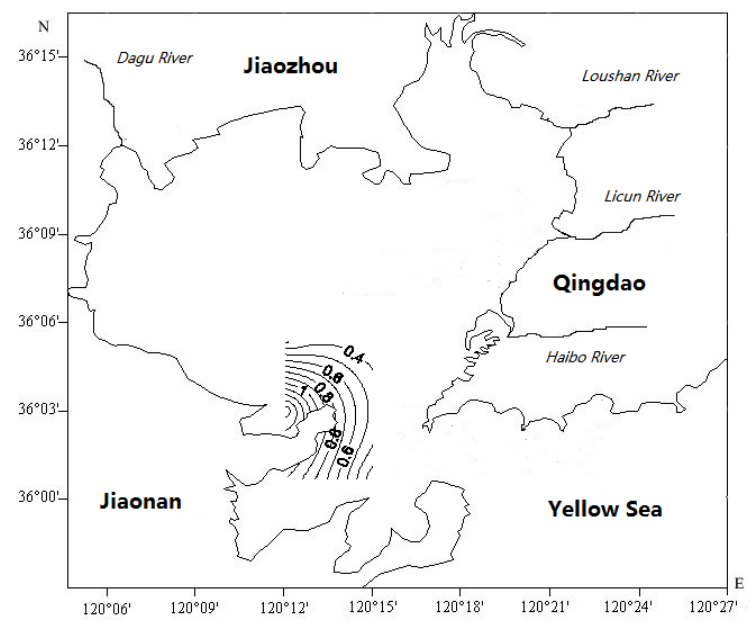

Fig. 2 Horizontal distribution of Cu in bottom waters in Jiaozhou Bay in July 1982/ $\mu \mathrm{g} \mathrm{L}^{-1}$

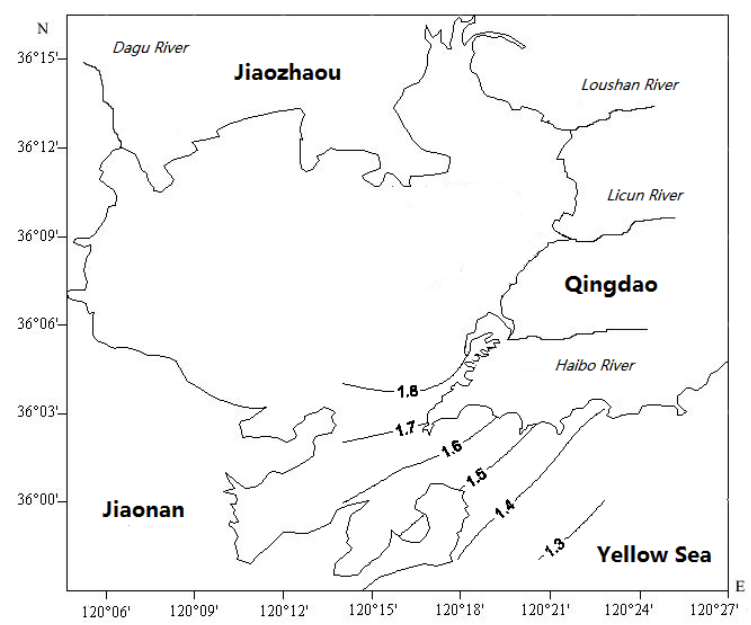

Fig. 3 Horizontal distribution of Cu in bottom waters in Jiaozhou Bay in September 1983/ $\mu \mathrm{g} \mathrm{L}^{-1}$

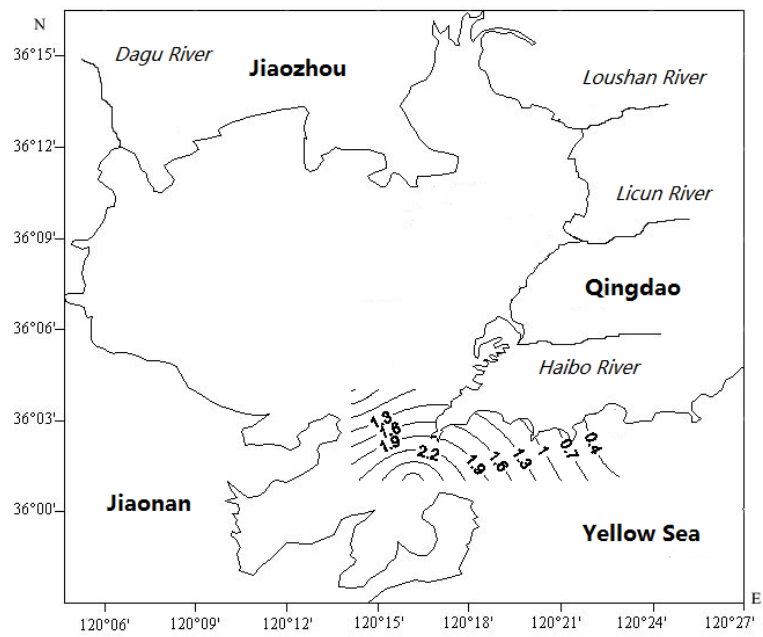

Fig. 4 Horizontal distribution of Cu in bottom waters in Jiaozhou Bay in July 1984/ $\mu \mathrm{g} \mathrm{L}^{-1}$ 


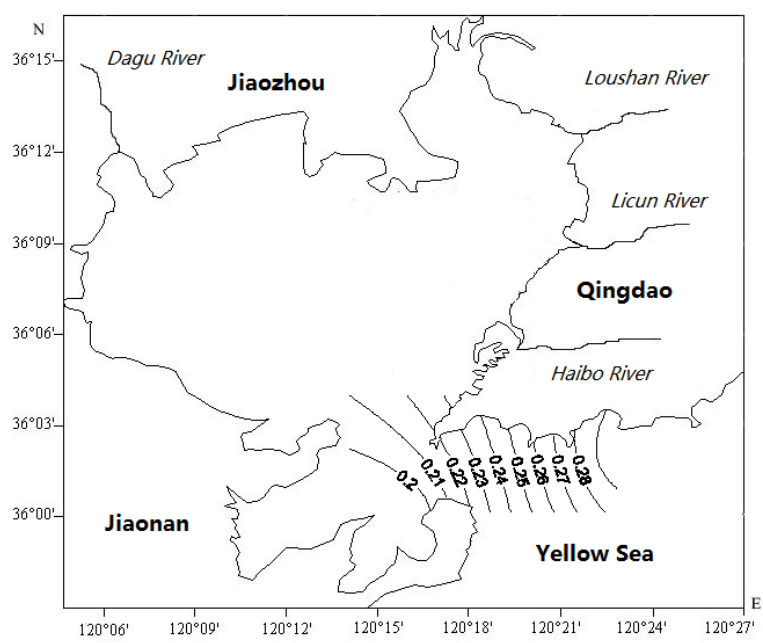

Fig. 5 Horizontal distribution of Cu in bottom waters in Jiaozhou Bay in October 1985/ $\mu \mathrm{g} \mathrm{L}^{-1}$

\section{Conclusions}

The horizontal distributions and the high settling regions of $\mathrm{Cu}$ in bottom waters in Jiaozhou Bay were analyzed and identified. The source input of $\mathrm{Cu}$ and the sedimentation of $\mathrm{Cu}$ were different in different season, resulted in the settling of $\mathrm{Cu}$ to bottom waters was varying among seasons. By means of horizontal water's effect, vertical water's effect, resulting the high value regions of $\mathrm{Cu}$ in bottom waters in Jiaozhou Bay.

\section{Acknowledgment}

This research was sponsored by the China National Natural Science Foundation (31560107), Doctoral Degree Construction Library of Guizhou Nationalities University, Education Ministry's New Century Excellent Talents Supporting Plan (NCET-12-0659) and Research Projects of Guizhou Nationalities University ([2014]02), Research Projects of Guizhou Province Ministry of Education (KY [2014] 266), Research Projects of Guizhou Province Ministry of Science and Technology (LH [2014] 7376).

\section{References}

[1] Yang DF and Miao ZQ: Marine Bay Ecology (I): Beijing, Ocean Precess, (2010), p. 1-320. (in Chinese)

[2] Yang DF and Gao ZH: Marine Bay Ecology (II): Beijing, Ocean Precess, (2010), p. 1-330. (in Chinese)

[3] Yang DF, Miao ZQ, Song WP, et al.: Advanced Materials Research, Vol.1092-1093 (2015), p. 1013-1016.

[4] Yang DF, Miao ZQ, Cui WL, et al.: Advances in intelligent systems research, (2015), p. 17-20.

[5] Yang DF, Wang FY, Zhu SX, et al.:Advances in Engineering Research, Vol. 31(2015): p. 1284-1287.

[6] Yang DF, Zhu SX, Wu YJ, et al.:Advances in Engineering Research, Vol. 31(2015): p. 1288-1291.

[7] Yang DF, Wang FY, Zhu SX, et al.: Materials Engineering and Information Technology Apllication, Vol. 2015, p. 554-557.

[8] Yang DF, Zhu SX, Zhao XL, et al.: Advances in Engineering Research, Vol. 40 (2015), p. 770-775. 
[9] Yang DF, Zhu SX, Wang FY, et al.:Advances in Computer Science Research, Vol. (2015), p. 1765-1769.

[10]Yang DF, Zhu SX, Wang FY, et al.: Advances in Engineering Research, Vol. 60(2016), p. 408-411.

[11]Yang DF, Zhu SX, Wang M, et al.: Advances in Engineering Research, Vol. 67(2016), p. 1311-1314.

[12] Yang DF, Yang DF, Wang M, et al.: Advances in Engineering Research, Vol. (2016), Part G, p. 1917-1920.

[13]Yang DF, Yang DF, He HZ, et al.: Advances in Engineering Research, Vol. 84 (2016), p. 852-856.

[14]Yang DF, He HZ, Wang FY, et al.: Advances in Materials Science,Energy Technology and Environmental Engineering, Vol. (2017), p. 291-294.

[15] Yang DF, Zhu SX, Yang DF, et al.: Computer Life, Vol. 4 (2016), p. 579-584.

[16]Yang DF, Yang DF, Tao XZ, et al.: World Scientific Research Journal, Vol. 22 (2016), p. 69-73.

[17] Yang DF, Chen Y, Gao ZH, et al.: Chinese Journal of Oceanology and Limnology, Vol. 23(2005), p. 72-90. (in Chinese)

[18] Yang DF, Wang FY, Gao ZH, et al. Marine Science, Vol. 28 (2004), p. 71-74. (in Chinese)

[19]China's State Oceanic Administration: The specification for marine monitoring (Ocean Press, Beijiang 1991), p.1-300. (in Chinese)

[20] Yang DF, Wang FY, He HZ, et al.: Proceedings of the 2015 international symposium on computers and informatics, 2015, p. 2655-2660.

[21]Yang DF, Wang FY, Zhao XL, et al.: Sustainable Energy and Enviroment Protection. 2015, p. 191-195.

[22]Yang DF, Wang FY, Yang XQ, et al.:Advances in Computer Science Research, Vol. 2352 (2015), p. 198-204. 